\title{
Neuroimaging studies of serotonin gene polymorphisms: Exploring the interplay of genes, brain, and behavior
}

\author{
SARAH M. BROWN and AHMAD R. HARIRI \\ University of Pittsburgh, Pittsburgh, Pennsylvania
}

\begin{abstract}
Because of the unique ability it provides to investigate information processing at the level of neural systems, functional neuroimaging is a powerful tool to explore the relationship between genes, brain, and behavior. Recently, functional neuroimaging has provided dramatic illustrations of how a promoter polymorphism in the human serotonin transporter gene, which has been weakly related to several dimensions of emotional behaviors (such as neuroticism and anxiety traits), is strongly related to the engagement of neural systems - namely, the amygdala and subgenual prefrontal cortex, subserving emotional information processing. This review will outline the experimental strategy by which these genetic effects on brain function have been explored and highlight the effectiveness of this strategy to delineate biological pathways and mechanisms contributing to the emergence of individual differences in brain function that potentially bias behavior and risk for psychiatric illness.
\end{abstract}

\section{Imaging Genetics: An Overview}

It is well accepted that both genes and environmental factors contribute to individual differences in brain function and behavior (Krubitzer \& Kahn, 2003; Moffitt, Caspi, \& Rutter, 2005). Although it is not clear to what degree each of these factors contributes to variation in brain function, it is likely that genes contribute to a significant portion of the variance. Recent scientific advances, such as a working draft of the human genome sequence, offer new opportunities to detect specific genetic variants that are associated with differences in behavioral traits. Technological advances in brain imaging techniques, such as blood oxygenation level dependent (BOLD) functional magnetic resonance imaging (fMRI), have allowed researchers to noninvasively investigate brain function at the level of information processing within discrete brain circuits supporting specific cognitive and emotional processes.

Moreover, the functional effects of candidate variants on brain function may be more readily measurable than the cognitive and emotional processes supported by these same mechanisms; thus, functional polymorphisms in genes weakly related to behaviors (and, by extension, psychiatric syndromes) may be more strongly related to the function of specific neural systems. This is the underlying assumption of what we have called imaging genomics (Hariri \& Weinberger, 2003), in which the phenotype is the physiologic response of the brain during specific information processing.

Correspondence relating to this article may be sent to A. R. Hariri, Department of Psychiatry, University of Pittsburgh School of Medicine, Western Psychiatric Institute and Clinic, 3811 O'Hara Street, Room E-729, Pittsburgh, PA 15213-2593 (e-mail: haririar@upmc.edu).
Ideally, imaging genetics studies will be targeted at genes with clearly defined functional polymorphisms that are associated with specific physiologic effects at the cellular level in distinct brain circuits. In the absence of detailed functional variants, genes of interest should be associated with identified single-nucleotide polymorphisms (SNPs) or other allele variants with likely functional implications involving circumscribed neuroanatomical systems. As with all genetic association analyses, imaging genetics studies must account for systematic nongenetic differences between genotype groups that could obscure or masquerade for a true gene effect. Such studies need to control for various demographics, such as age, gender, or IQ; population heterogeneity and substructure (i.e., "stratification"); as well as environmental factors such as illness, injury, or substance abuse. In addition, imaging genetics studies must consider variability in imaging task performance in interpreting potential gene effects, because typical imaging signals (e.g., the BOLD response in fMRI) are linked closely with performance.

Experimental tasks employed in imaging genetics should consistently engage circumscribed brain circuits, produce robust signals, and demonstrate variance across subjects in order to allow for the determination of gene effects. For these reasons, initial imaging genetics studies of specific allelic variants may benefit from traditional blocked design paradigms that maximize the detection efficacy of neuroimaging experiments (Birn, Cox, \& Bandettini, 2002). Event-related fMRI designs, which allow for a more detailed estimation of hemodynamic onset, delay, and amplitude for independent events, can be applied once genetic effects on specific brain regions have been identified using more traditional approaches. These designs may also offer additional advantages in parsing 
subprocesses of information processing on which genotype has a greater impact than it does on processes reflecting global task characteristics.

Functional neuroimaging, by allowing the rapid acquisition of hundreds of repeated measures of brain function within a single subject, offers a unique and potentially profound avenue to investigate gene effects by examining their influence on the activity of specific brain circuits during the processing of discrete stimuli or the performance of distinct behaviors. Moreover, the power afforded by these methods (i.e., both the statistical advantages of signal oversampling and averaging and the biological advantages of prebehavioral phenotypes) may allow investigators to identify robust gene effects on brain information processing in considerably fewer subjects (10s vs. $100 \mathrm{~s})$ than is possible in typical behavioral studies, and with much greater sensitivity (10-20 times) than their behavioral counterparts. Ideally, associations between gene variants and regional patterns of brain information processing will not only elucidate the biological mechanisms underlying previous links with behavior but also serve to direct attention to new behaviors that are mediated by brain systems influenced by the variants, and vice versa.

\section{Serotonin-Transporter Genetic Variation and Individual Differences in Emotional Behavior}

Converging evidence from animal and human studies has revealed that serotonin (5-hydroxytryptamine; 5-HT) is a critical neuromodulator in the generation and regulation of emotional behavior (Lucki, 1998): Genetic variation in several key 5-HT subsystems, presumably resulting in altered central serotonergic tone and neurotransmission, has been associated with various aspects of personality and temperament, as well as with susceptibility to affective illness (Murphy et al., 1998; Reif \& Lesch, 2003). Moreover, serotonergic neurotransmission has also been an effective target for the pharmacological treatment of mood disorders, including depression, obsessive-compulsive disorder, anxiety, and panic (Blier \& de Montigny, 1999).

The serotonin transporter (5-HTT) plays an important role in serotonergic neurotransmission by facilitating reuptake of 5-HT from the synaptic cleft (Amara \& Kuhar, 1993; Blakely \& Bauman, 2000). This active reuptake mechanism facilitates the termination of postsynaptic serotonergic effects mediated by a broad array of 5-HT receptors (Gu, 2002). In addition to its role in regulating postsynaptic signaling, the 5-HTT is critical for the maintenance of 5-HT signaling or "tone" via its role of complementing de novo biosynthesis of 5-HT with recovery of the neurotransmitter from the synapse (Mathews et al., 2004; Shen et al., 2004). Thus, by contributing to both the release and reuptake of 5-HT, the 5-HTT occupies a unique position in the regulation of 5-HT neurotransmission. As such, the 5-HTT further represents an invaluable foothold from which to begin studies of the impact of genetically driven variation in 5-HT function on neural mechanisms underlying emotional behaviors.

In 1996, a relatively common polymorphism was identified in the human 5-HTT gene (SLC6A4) located on chromosome 17q11.1-q12 (Heils et al., 1996). The polymorphism is a variable repeat sequence in the promoter region (5-HTTLPR) resulting in two common alleles: the short (S) variant, comprising 14 copies of a 20-23 imperfect base pair repeat unit, and the long (L) variant, comprising 16 copies. In populations of European ancestry, the frequency of the $\mathrm{S}$ allele is approximately .40 , and the genotype frequencies are in Hardy-Weinberg equilibrium $(\mathrm{L} / \mathrm{L}=.36, \mathrm{~L} / \mathrm{S}=.48, \mathrm{~S} / \mathrm{S}=.16)$. These relative allele frequencies, however, can vary substantially across populations (Gelernter, Kranzler, \& Cubells, 1997).

Following the identification of this polymorphism, Lesch and colleagues demonstrated that individuals carrying the short allele are slightly more likely to display abnormal levels of anxiety than are L/L homozygotes (Lesch et al., 1996). Since this original report, others have confirmed the association between the 5-HTTLPR short allele and heightened anxiety (Du, Bakish, \& Hrdina, 2000; Katsuragi et al., 1999; Mazzanti et al., 1998; Melke et al., 2001; Munafo, Clark, \& Flint, 2005; Schinka, Busch, \& Robichaux-Keene, 2004; Sen, Burmeister, \& Ghosh, 2004) and have also demonstrated that individuals possessing the short allele more readily acquire conditioned fear responses (Garpenstrand, Annas, Ekblom, Oreland, $\&$ Fredrikson, 2001) and develop affective illness (Lesch \& Mössner, 1998), in comparison with individuals homozygous for the long allele. Infants homozygous for the $\mathrm{S}$ allele have similar increases in anxiety-related measures (Auerbach, Faroy, Ebstein, Kahana, \& Levine, 2001; Auerbach et al., 1999).

Recent studies utilizing pharmacological challenge paradigms of the 5-HT system suggest that these differences in affect, mood, and temperament may reflect 5-HTTLPRdriven variation in 5-HTT expression and subsequent changes in synaptic concentrations of 5-HT (Moreno et al., 2002; Neumeister et al., 2002; Whale, Clifford, \& Cowen, 2000). Furthermore, reduced 5-HTT availability, as putatively indexed by the 5-HTTLPR short allele, has been associated with mood disturbances, including major depression (especially in the context of environmental stressors; Caspi et al., 2003; Eley et al., 2004; Kaufman et al., 2004; Kendler, Kuhn, Vittum, Prescott, \& Riley, 2005; Malison et al., 1998), as well as with more severe depression and anxiety in various psychiatric disorders (Eggers et al., 2003; Heinz et al., 2002; Willeit et al., 2000).

Several additional studies have failed to identify a relationship between 5-HTTLPR genotype and subjective measures of emotion and personality or mood disorders (Ball et al., 1997; Deary et al., 1999; Flory et al., 1999; Gillespie, Whitfield, Williams, Heath, \& Martin, 2005; Glatt \& Freimer, 2002; Katsuragi et al., 1999). Such replication failures may reflect inadequate control for nongenotype factors such as gender and ethnicity (Williams et al., 2003), chronic alcohol use (Heinz et al., 2000; Little et al., 1998), and exposure to environmental stress (Caspi et al., 2003), all of which have been shown to influence the effect of the 5-HTTLPR on both brain and behavior (see also Reif \& Lesch, 2003). In addition, these inconsistencies may reflect the failure to account for possible interactions of 
5-HTTLPR with other genes within the serotonin system (Cho et al., 2005; Hranilovic et al., 2004; Hu et al., 2005; Zalsman et al., 2005) that affect other neurotransmitter systems known to be important for affective behavior (e.g., dopamine and norepinephrine).

Simply put, genes do not encode behaviors. Instead, biology dictates that allelic variants will most likely have a functional impact on the cellular and molecular pathways associated with a gene. The resulting subtle cellular and molecular alterations may in turn produce response biases at the systems level (i.e., in brain circuits that serve as essential intermediates of behavior), which ultimately may or may not affect overt behavior. This inherently weak relationship between a genotype and a particular behavioral phenotype limits the power of genetic association in studies of human temperament and emotion.

\section{Imaging Genetics of the 5-HTTLPR and Amygdala Reactivity}

Although the potential influence of genetic variation in 5-HTT function on human mood and temperament was bolstered by subsequent studies demonstrating increased anxiety-like behavior and abnormal fear conditioning in 5-HTT knockout mice (Holmes, Li, Murphy, Gold, \& Crawley, 2003), the underlying neurobiological correlates of this functional relationship remained obscure until recently. As with serotonin, the amygdala is a brain structure central in the generation of both normal and pathological emotional behavior (LeDoux, 2000). Furthermore, the amygdala is densely innervated by serotonergic neurons, and 5-HT receptors are abundant throughout amygdala subnuclei (Azmitia \& Gannon, 1986; Sadikot \& Parent, 1990; Smith, Daunais, Nader, \& Porrino, 1999). Thus, the activity of this subcortical region may be uniquely sensitive to alterations in serotonergic neurotransmission, and any resulting variability in amygdala excitability is likely to contribute to individual differences in emergent phenomena such as mood and temperament.
In 2002, we used BOLD fMRI to directly evaluate the impact of the 5-HTTLPR on the physiological response of the human amygdala to biologically salient environmental stimuli. In this initial study, conducted at NIMH, healthy adult volunteers from two independent cohorts ( $n=14$ in each) were divided into equal groups based on their 5-HTTLPR genotype, with the groups matched for age, gender, IQ, and task performance. During BOLD fMRI scanning, the subjects performed a simple perceptual processing task involving the matching of fearful and angry human facial expressions that has been effective at consistently engaging the amygdala across multiple subject populations and experimental paradigms (Hariri, Bookheimer, \& Mazziotta, 2000; Hariri, Mattay, Tessitore, Fera, et al., 2002; Hariri, Tessitore, Mattay, Fera, \& Weinberger, 2002; Tessitore et al., 2002). The fMRI data revealed that subjects carrying the less efficient 5-HTTLPR $\mathrm{S}$ allele exhibited significantly increased amygdala activity, as indexed by the BOLD signal, in comparison with subjects homozygous for the L allele (Hariri, Mattay, Tessitore, Kolachana, et al., 2002). In fact, the difference in amygdala activity between 5-HTTLPR genotype groups in this study was nearly fivefold, accounting for $20 \%$ of the total variance in the amygdala response during this experiment, an effect size greater than any previously reported behavioral associations. This initial finding suggested that the increased anxiety and fearfulness associated with individuals possessing the 5-HTTLPR S allele may reflect the hyperresponsiveness of their amygdala to relevant environmental stimuli.

Recently, five independent functional imaging studies (see Table 1) have reported identical 5-HTTLPR S-alleledriven amygdala hyperreactivity in cohorts of healthy German (Heinz et al., 2005), Italian (Bertolino et al., 2005), and American (Canli et al., 2005) adult volunteers, as well as in Dutch patients with social phobia (Furmark et al., 2004). We have also replicated this finding in a sample of healthy adult volunteers from our ongoing imaging genet-

Table 1

Imaging Genetics Studies of 5-HTTLPR Effects on Amygdala Reactivity

\begin{tabular}{|c|c|c|c|c|c|c|c|c|c|}
\hline \multirow[b]{2}{*}{ Author } & \multirow[b]{2}{*}{ Year } & \multirow{2}{*}{$\begin{array}{c}\text { Sample } \\
\text { Demographic }\end{array}$} & \multirow[b]{2}{*}{$N$} & \multirow[b]{2}{*}{ Task Stimuli } & \multirow[b]{2}{*}{ Hem. } & \multicolumn{3}{|c|}{ Talairach Coord. } & \multirow[b]{2}{*}{ Results } \\
\hline & & & & & & $x$ & $y$ & $z$ & \\
\hline \multirow[t]{2}{*}{$\begin{array}{l}\text { Hariri } \\
\quad \text { et al. }\end{array}$} & 2002 & American & 14 & $\begin{array}{l}\text { Angry and fearful facial } \\
\text { expressions }\end{array}$ & $\mathrm{R}$ & 24 & -8 & -16 & \multirow[t]{2}{*}{$\begin{array}{l}\text { Greater right amygdala activity in } \\
\text { healthy adult S-allele carriers }\end{array}$} \\
\hline & & American & 14 & & $\mathrm{R}$ & 28 & -4 & -16 & \\
\hline $\begin{array}{l}\text { Furmark } \\
\text { et al. }\end{array}$ & 2004 & Dutch & 17 & Public speaking task & $\mathrm{R}$ & \multicolumn{3}{|c|}{ PET $\mathrm{H}_{2} \mathrm{O}_{15}$} & $\begin{array}{l}\text { Greater right amygdala activity in } \\
\text { S-allele carriers with social phobia }\end{array}$ \\
\hline \multirow[t]{2}{*}{$\begin{array}{l}\text { Heinz } \\
\text { et al. }\end{array}$} & 2005 & German & 29 & $\begin{array}{l}\text { Aversive, pleasant, and } \\
\text { neutral pictures }\end{array}$ & $\mathrm{R}$ & 27 & -1 & -13 & \multirow[t]{2}{*}{$\begin{array}{l}\text { Greater right and left amygdala activity } \\
\text { in healthy adult S-allele carriers }\end{array}$} \\
\hline & & & & & $\mathrm{L}$ & -24 & -1 & -13 & \\
\hline $\begin{array}{l}\text { Bertolino } \\
\text { et al. }\end{array}$ & 2005 & Italian & 28 & $\begin{array}{l}\text { Angry and fearful facial } \\
\text { expressions }\end{array}$ & $\mathrm{R}$ & 25 & -8 & -14 & $\begin{array}{l}\text { Greater right amygdala activity in } \\
\text { healthy adult S-allele carriers }\end{array}$ \\
\hline $\begin{array}{l}\text { Hariri } \\
\quad \text { et al. }\end{array}$ & 2005 & American & 92 & $\begin{array}{l}\text { Angry and fearful facial } \\
\text { expressions }\end{array}$ & $\mathrm{R}$ & 18.8 & -8.4 & 7.8 & $\begin{array}{l}\text { Greater right amygdala activity in } \\
\text { healthy adult S-allele carriers }\end{array}$ \\
\hline Canli et al. & 2005 & American & 41 & $\begin{array}{l}\text { Negative, positive, and } \\
\text { neutral words }\end{array}$ & $\mathrm{R}$ & $22^{*}$ & $-2^{*}$ & $-14^{*}$ & $\begin{array}{l}\text { Greater right amygdala activity in } \\
\text { healthy adult S-allele carriers }\end{array}$ \\
\hline $\begin{array}{l}\text { Pittsburgh } \\
\text { study }\end{array}$ & $\begin{array}{l}2005(\text { See } \\
\text { Figure } 1)\end{array}$ & American & 55 & $\begin{array}{l}\text { Angry, fearful, and neutral } \\
\text { facial expressions }\end{array}$ & $\mathrm{R}$ & 18 & -10 & -13 & $\begin{array}{l}\text { Greater right amygdala activity in } \\
\text { healthy adult S-allele carriers }\end{array}$ \\
\hline
\end{tabular}

*MNI coordinates. 
ics studies at the University of Pittsburgh (see Figure 1). Moreover, our research group at NIMH has recently replicated the finding of 5-HTTLPR S effects on amygdala reactivity in a large, independent cohort of healthy adult volunteers $(n=92$; Hariri et al., 2005). In this replication, we further demonstrated that 5-HTTLPR S-allele-driven amygdala hyperresponsivity is equally pronounced in both sexes and independent of S-allele load. The equivalent effect of one or two $\mathrm{S}$ alleles on amygdala function is consistent with the original observations of Lesch et al. (1996) on the influence of the 5-HTTLPR on in vitro gene transcription efficiency and subsequent 5-HTT availability. The absence of sex differences suggests that the increased prevalence of mood disorders in females may be related to factors other than the direct risk effect of the 5-HTTLPR S allele.

\section{The 5-HTTLPR and the Development of Corticolimbic Circuitry}

In addition to its potent neuromodulatory effects on brain activity and responsivity, 5-HT plays a significant

A
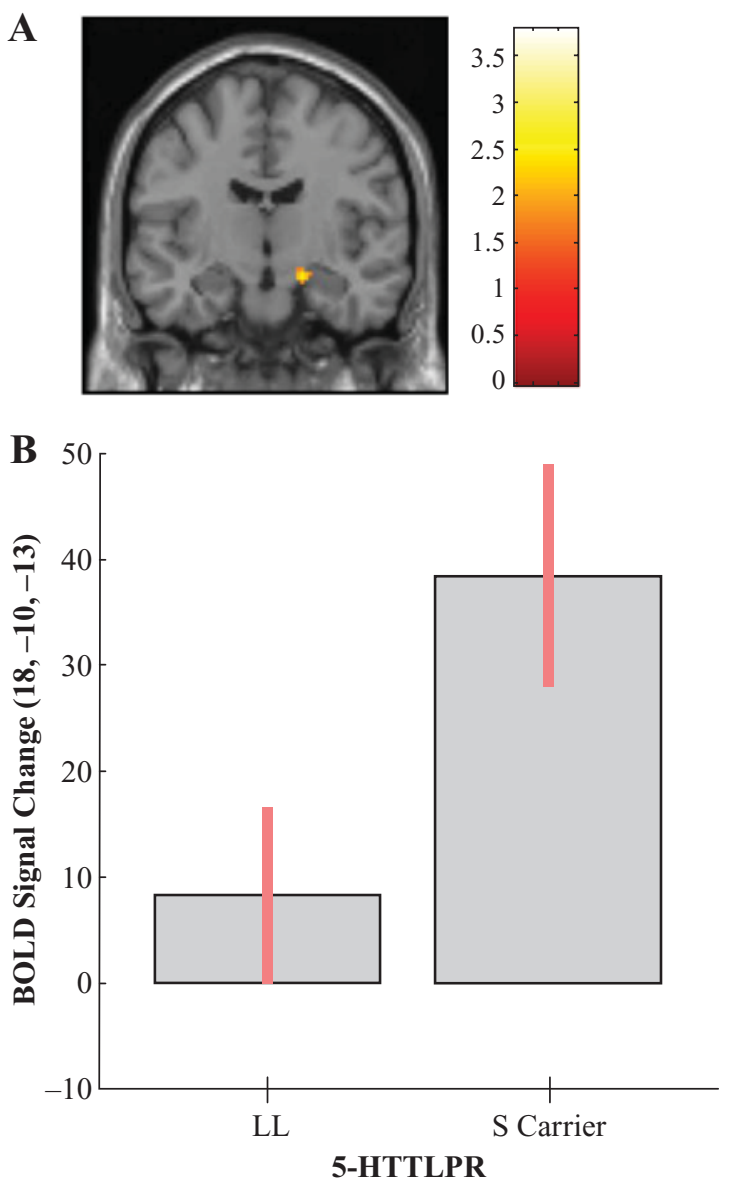

Figure 1. (A) Statistical parametric map illustrating greater right amygdala activity in S-allele carriers $(n=34)$ in comparison with $L$-allele homozygotes $(n=21)$. Differential amygdala activity is shown overlaid onto an average structural MRI. (B) Contrast estimates and $\mathbf{9 0 \%}$ confidence intervals for the maximal voxel $(18,-10,-13)$ in the right amygdala cluster from panel $A$. role in the development of the central nervous system (Gaspar, 2004), and disruption of 5-HT signaling leads to aberrant cortical organization and associated function (Lesch, 2001; Lesch \& Mössner, 1998). The impact of variation in 5-HT signaling associated with the 5-HTTLPR has recently been explored using voxel-based morphometric analyses of structural magnetic resonance data in a large sample $(N=114)$ of healthy adults (Pezawas et al., 2005). These analyses revealed well-circumscribed effects of the 5-HTTLPR on corticolimbic brain circuitry. Specifically, in comparison with the L-allele homozygotes, S-allele carriers showed significantly reduced gray matter volume of the perigenual anterior cingulate cortex (pACC) and amygdala. Moreover, S-allele carriers showed significantly lower structural covariation between the amygdala and the subgenual anterior cingulate than did L homozygotes. This suggests that the pACC and amygdala represent a functional circuit whose morphological development is modulated by genetic variation in the serotonergic system. 5-HTTLPR S-allele-associated relative reductions in corticolimbic gray matter volume have recently been replicated by Canli et al. (2005).

The finding of Pezawas et al. (2005) of altered corticolimbic gray matter volume prompted subsequent exploration of the impact of these observed structural effects on the functional interactions of the amygdala and pACC in corresponding fMRI data from our studies at NIMH. Independent of 5-HTTLPR genotype status, we found that the amygdala and pACC were significantly functionally connected. Two distinct regions of functional connectivity were identified within the pACC - a positive coupling between the amygdala and the subgenual cingulate, and a negative coupling between the amygdala and the supragenual cingulate. These cingulate regions also showed strong positive connectivity with each other, suggesting that the corticolimbic feedback loop is closed via local processing within the cingulate cortex. This intrinsic cingulate connection also is consistent with anatomical studies in nonhuman primates (Barbas, 2000; Carmichael \& Price, 1995; Cavada, Company, Tejedor, Cruz-Rizzolo, \& Reinoso-Suarez, 2000). Remarkably, 5-HTTLPR S-allele carriers showed a significant reduction of amygdala-pACC functional connectivity in comparison with $\mathrm{L}$ homozygotes. This difference was most pronounced in the coupling of amygdala and subgenual ACC. These findings suggest that a disruption of this amygdala-pACC feedback circuitry could underlie the earlier observation of increased amygdala activity in S carriers during the processing of biologically salient stimuli (Hariri et al., 2005; Hariri, Mattay, Tessitore, Kolachana, et al., 2002). More specifically, the data suggest that the overactivation of the amygdala associated with the 5-HTTLPR S allele may reflect a relative failure of cortical integration and regulation of the amygdala response, rather than an abnormal primary response per se. Taken together, these data show that 5 HTTLPR genotype affects the structure and putative wiring of a core region within the limbic system thought to be crucial for depression- and anxiety-related temperamental traits (Mayberg, 2003a, 2003b; Phillips, Drevets, Rauch, \& Lane, 2003a, 2003b). These findings thus suggest a mecha- 
nism linking developmental alterations in 5-HT-dependent neuronal pathways to impaired interactions in a regulatory network related to emotional reactivity.

The collective results of these imaging genetics studies reveal that the 5-HTTLPR S allele has a robust effect on human amygdala structure and function, as well as on the functional interactions of corticolimbic circuitry implicated in both normal and pathological mood states. In addition, the absence of group differences in age, gender, IQ, and ethnicity in each of these studies indicates that the observed effects are not likely a reflection of systematic variation in such nongenotype factors. Rather, the data suggest that heritable variation in 5-HT signaling associated with the 5-HTTLPR results in structural alterations of amygdala and pACC, accompanied by biased amygdala reactivity and functional coupling with pACC in response to salient environmental cues. Furthermore, the emergence of these effects in samples of ethnically matched volunteers carefully screened to exclude any lifetime history of psychiatric illness or treatment argues that they represent genetically determined biological traits not related to manifest psychiatric illness.

\section{The 5-HTTLPR Corticolimbic Circuitry and Temperament}

Although these functional imaging studies have demonstrated a significant difference on the neural level between S-allele carriers and L-allele homozygotes, the effect of the $\mathrm{S}$ allele on trait anxiety is modest at best, accounting for approximately $4 \%$ of the phenotypic variance (Lesch et al., 1996). Specifically, in both our initial (Hariri, Mattay, Tessitore, Kolachana, et al., 2002) and replication studies (Hariri et al., 2005), we did not find any significant 5-HTTLPR genotype association with subjective behavioral measures of anxiety-like or fear-related traits, as indexed by the harm avoidance (HA) component of the Tridimensional Personality Questionnaire, a putative personality measure related to trait anxiety and 5-HT function (Cloninger, 1986; Cloninger, Svrakic, \& Przybeck, 1993). The low predictive value of the 5-HT polymorphism genotype allows for multiple interacting mechanisms, including, of course, additional genes. This failure to find a behavioral association is not surprising, given the relatively small sample sizes of each study, and thus their limited power to detect likely small (e.g., 1\%-5\%) genetically mediated differences in behavior. Moreover, recent research supports the possibility that gene-environment interactions account for a portion of the additional variance on behavioral phenotypes (Caspi et al., 2002; Caspi et al., 2003; Eley et al., 2004; Kaufman et al., 2004; Kendler et al., 2005; Manuck et al., 2005; Manuck, Flory, Ferrell, \& Muldoon, 2004).

Somewhat more surprising, however, was the absence of any predictive relationship between amygdala reactivity and HA. Given the critical role for the amygdala in detecting potential environmental threat and harnessing available resources for appropriate reactions, one might expect that its reactivity to such stimuli would predict individual differences in a temperamental trait such as HA. A convergence of evidence from animal and human studies, however, clearly demonstrates that emotional behaviors, especially those as complex as HA, are likely influenced by a densely interconnected and distributed cortical and subcortical circuitry, of which the amygdala is only one component. Therefore, we examined the relationship between HA and the observed 5-HTTLPR effects on the functional connectivity of amygdala and pACC.

In these analyses, we hypothesized that if abnormal functional dynamics of the amygdala-pACC affective circuit underlies reported associations of the 5-HTTLPR with emotional phenotypes, functional connectivity indices between these regions should predict normal variation in temperamental trait measures related to anxiety and depression, such as HA. These analyses revealed a striking pattern, wherein nearly $30 \%$ of the variance in HA scores was predicted by our measure of amygdala-pACC functional connectivity (Pezawas et al., 2005). However, as in our previous studies (Hariri et al., 2005; Hariri, Mattay, Tessitore, Kolachana, et al., 2002), functional (or structural) measures of single brain regions (i.e., amygdala or pACC) were of no predictive value. Thus, 5-HTTLPRmediated corticolimbic functional connectivity alterations are manifested in anxiety-related temperamental traits, possibly reflecting inadequate regulation and integration of amygdala-mediated arousal, leading to an increased vulnerability to persistent negative affect, and eventually to depression in a context of accumulating environmental adversity. Although investigations of localized structural and functional abnormalities have provided insights about mood disorders, our data underscore the importance of studying genetic mechanisms of complex brain disorders at the level of dynamically interacting neural systems. Such relationships may better capture the functional consequences of neurodevelopmental processes altering circuitry function implicated in human temperament and psychiatric disorders.

\section{Other Candidate 5-HT Synthesis Genes}

Of the many allelic variants identified in serotonergic genes, those representing critical bottlenecks in serotonin synthesis, reuptake, and metabolism may lead to the most dramatic alterations in serotonergic neurotransmission and, consequently, the functional integrity of affective brain circuits. For example, a promoter polymorphism in the human MAOA gene, responsible for the intracellular catabolism of 5-HT to 5-HIAA, has been associated with altered transcriptional activity and heightened levels of aggression and impulsivity in men (Caspi et al., 2002; Manuck et al., 1999; Manuck, Flory, Ferrell, Mann, \& Muldoon, 2000). Similarly, a polymorphism of putative functional significance in the human gene for aromatic L-amino acid decarboxylase (AADC), responsible for the conversion of 5-hydroxytryptophan to 5-HT, has been associated with bipolar disorder (Borglum et al., 1999). Finally, a frequent SNP in the human gene for tryptophan hydroxylase (TPH), the rate-limiting enzyme responsible for catalyzing the oxygenation of tryptophan to 5-hydroxytryptophan, has been associated with increased risk of suicide, impul- 
sivity, aggression, and alcoholism (Abbar et al., 2001; Manuck et al., 1999; New et al., 1998; Nielsen et al., 1994; Nielsen, Jenkins, Stefanisko, Jefferson, \& Goldman, 1997; Nielsen et al., 1998; Nolan, Volavka, Lachman, \& Saito, 2000). Recent work in TPH knockout mice has revealed the existence of a second TPH gene (TPH2), located on Chromosome 12, that is exclusively expressed in the murine brain and is responsible for regulating TPH expression and 5-HT synthesis in the murine central nervous system (Walther \& Bader, 2003; Walther et al., 2003).

\section{Genetic Variation in Human TPH2 and Amygdala Reactivity}

Recently, our research group at the University of Pittsburgh demonstrated the first in vivo significance of human TPH2 (hTPH2) in the brain by establishing an association between a frequent regulatory SNP in $h T P H 2$ and the reactivity of the amygdala (Brown et al., 2005). Specifically, an SNP in the upstream regulatory region of $h T P H 2$, resulting in a specific G-to-T allele substitution ( $\mathrm{T}$ allele, $38 \%$ ), affected the reactivity of the amygdala to affective facial expressions. Our study revealed that $h T P H 2 \mathrm{~T}$-allele carriers exhibit relatively greater activity in the amygdala than do G-allele homozygotes. Notably, the right dorsal amygdala cluster identified in this study exhibits significant overlap with the area associated with the 5-HTTLPR S allele (Bertolino et al., 2005; Canli et al., 2005; Furmark et al., 2004; Hariri et al., 2005; Hariri, Mattay, Tessitore, Kolachana, et al., 2002; Heinz et al., 2005). This genetically driven bias in the functional reactivity of the amygdala suggests that the promoter variant impacts the expression of TPH and the subsequent synthesis and availability of 5-HT.

In addition to providing further insight into the biological significance of $h T P H 2$ in the human central nervous system, this study marks an important advance in the application of functional neuroimaging to the study of genes, brain, and behavior. In contrast with the studies of genetic effects on brain function in which the molecular and cellular effects of the candidate variants had been previously demonstrated (e.g., 5-HTTLPR [Hariri, Mattay, Tessitore, Kolachana, et al., 2002], MAOA [Fan, Fossella, Sommer, $\mathrm{Wu}, \&$ Posner, 2003], COMT [Egan et al., 2001], and BDNF [Hariri et al., 2003]), our fMRI data provide the first evidence that an SNP in the regulatory region of the human TPH2 gene likely affects biological function. In this way, the initial identification of a systems-level effect of a specific polymorphism provides impetus for the subsequent characterization of its functional effects at the molecular and cellular levels. Thus, this study highlights the potentially reciprocal way that functional imaging and molecular genetics approaches can be mutually informative in advancing our understanding of the biological mechanisms of behavior.

However, such novel genetic findings illustrate the need to exercise caution in the selection of candidate genes while our knowledge of the genetic architecture continues to expand. For example, in the absence of detailed information regarding the functional effects of specific variants on gene expression [e.g., hTPH2 G(-844)T], associations between such variants and systems-level brain phenotypes may actually reflect the impact of other functional variants that are in linkage disequilibrium with the candidate under study. Moreover, the effect of any specific polymorphism may be exaggerated or minimized, depending on the context provided by other genes and the interaction of genes and environment. Imaging genomics, by virtue of its power to detect highly significant gene effects on brain information processing in relatively small samples, provides an ideal avenue through which a genetic profile can be identified that reflects the additive, or perhaps even multiplicative, interactions of these and other gene variants underlying the emergence of individual differences in affect and temperament and the diathesis of mood disorders.

\section{Summary and Future Directions}

A focus on brain phenotypes allows for a more incisive assessment of genetic effects - as evidenced by multiple replications of 5-HTTLPR effects on amygdala reactivity - by examining biological systems more proximate to underlying molecular and cellular effects of specific genetic variants. This increased power and sensitivity is reflected in the dramatically reduced sample sizes- -10 s rather than 100 s - required to demonstrate robust genetic effects on brain function. Moreover, understanding genetic effects on distinct brain circuitry (e.g., amygdala and medial prefrontal cortex) has the potential to inform many different behavioral phenotypes (e.g., fear, anxiety, impulsivity, and aggression) dependent on and supported by the underlying circuitry. Perhaps most importantly, such studies of genetic effects on brain structure and function allow for the identification of specific biological pathways and mechanisms by which genetic polymorphisms affect behavior. It is only with such a biological understanding that we can begin to develop more effective therapeutic and prevention strategies targeting the etiology of psychiatric illness.

Although imaging genetics provides a powerful new approach to the study of genes, brain, and behavior, its true potential will only be realized by aggressively expanding the scope and scale of the experimental protocols. Although single-gene effects on brain function can be readily documented in samples as small as 14 subjects, the contributions of multiple genes acting in response to variable environmental pressures is ultimately necessary for the development of truly predictive markers that account for the majority of variance in any given phenotype, such as stress resiliency. Ultimately, we anticipate that such a mechanistic understanding will allow for the early identification of individuals at greater risk for emotional regulatory problems that can have long-term health-related implications.

\section{REFERENCES}

Abbar, M., Courtet, P., Bellivier, F., Leboyer, M., Boulenger, J. P., Castelhau, D., ET AL. (2001). Suicide attempts and the tryptophan hydroxylase gene. Molecular Psychiatry, 6, 268-273.

Amara, S. G., \& KuHar, M. J. (1993). Neurotransmitter transporters: Recent progress. Annual Review of Neuroscience, 16, 73-93.

Auerbach, J. G., Faroy, M., Ebstein, R., Kahana, M., \& Levine, J. 
(2001). The association of the dopamine D4 receptor gene (DRD4) and the serotonin transporter promoter gene (5-HTTLPR) with temperament in 12-month-old infants. Journal of Child Psychology \& Psychiatry, 42, 777-783.

Auerbach, J. [G.], Geller, V., Lezer, S., Shinwell, E., Belmaker, R. H., Levine, J., \& Ebstein, R. (1999). Dopamine D4 receptor (D4DR) and serotonin transporter promoter (5-HTTLPR) polymorphisms in the determination of temperament in 2-month-old infants. Molecular Psychiatry, 4, 369-373.

Azmitia, E. C., \& Gannon, P. J. (1986). The primate serotonergic system: A review of human and animal studies and a report on Macaca fascicularis. Advanced Neurology, 43, 407-468.

Ball, D., Hill, L., Freeman, B., Eley, T. C., Strelau, J., Riemann, R., ET AL. (1997). The serotonin transporter gene and peer-rated neuroticism. NeuroReport, 8, 1301-1304.

BARBAS, H. (2000). Connections underlying the synthesis of cognition, memory, and emotion in primate prefrontal cortices. Brain Research Bulletin, 52, 319-330.

Bertolino, A., Arciero, G., Rubino, V., Latorre, V., De Candia, M., Mazzola, V., ET AL. (2005). Variation of human amygdala response during threatening stimuli as a function of $5^{\prime}$ HTTLPR genotype and personality style. Biological Psychiatry, 57, 1517-1525.

Birn, R. M., Cox, R. W., \& BandetTini, P. A. (2002). Detection versus estimation in event-related fMRI: Choosing the optimal stimulus timing. NeuroImage, $\mathbf{1 5}, 252-264$.

BlaKely, R. D., \& BaUman, A. L. (2000). Biogenic amine transporters: Regulation in flux. Current Opinion in Neurobiology, 10, 328-336.

Blier, P., \& De Montigny, C. (1999). Serotonin and drug-induced therapeutic responses in major depression, obsessive-compulsive and panic disorders. Neuropsychopharmacology, 21, 91S-98S.

Borglum, A. D., Bruun, T. G., Kueldsen, T. E., Ewald, H., Mors, O., KIROV, G., ET AL. (1999). Two novel variants in the DOPA decarboxylase gene: Association with bipolar affective disorder. Molecular Psychiatry, 4, 545-551.

Brown, S. M., Peet, E., Manuck, S. B., Williamson, D. E., Dahl, R. E., Ferrell, R. E., \& Hariri, A. R. (2005). A regulatory variant of the human tryptophan hydroxylase- 2 gene biases amygdala reactivity. Molecular Psychiatry, 10, 805, 884-888

Canli, T., Omura, K., Haas, B. W., Fallgatter, A., Constable, R. T., \& LESCH, K. P. (2005). Beyond affect: A role for genetic variation of the serotonin transporter in neural activation during a cognitive attention task. Proceedings of the National Academy of Sciences, 102, 12224-12229.

Carmichael, S. T., \& Price, J. L. (1995). Limbic connections of the orbital and medial prefrontal cortex in macaque monkeys. Journal of Comparative Neurology, 363, 615-641.

Caspi, A., McClay, J., Moffitt, T. E., Mill, J., Martin, J., Craig, I. W., ET AL. (2002). Role of genotype in the cycle of violence in maltreated children. Science, 297, 851-854.

Caspi, A., Sugden, K., Moffitt, T. E., Taylor, A., Craig, I. W., HarRINGTON, H., ET AL. (2003). Influence of life stress on depression Moderation by a polymorphism in the 5-HTT gene. Science, $\mathbf{3 0 1}$ 386-389.

Cavada, C., Company, T., Tejedor, J., Cruz-Rizzolo, R. J., \& ReinosoSUAREZ, F. (2000). The anatomical connections of the macaque monkey orbitofrontal cortex: A review. Cerebral Cortex, 10, 220-242.

Cho, H. J., Meira-Lima, I., Cordeiro, Q., Michelon, L., Sham, P., Vallada, H., \& Collier, D. A. (2005). Population-based and familybased studies on the serotonin transporter gene polymorphisms and bipolar disorder: A systematic review and meta-analysis. Molecular Psychiatry, 10, 771-781.

Cloninger, C. R. (1986). A unified biosocial theory of personality and its role in the development of anxiety states. Psychiatric Developments, 4, 167-226.

Cloninger, C. R., Svrakic, D. M., \& Przybeck, T. R. (1993). A psychobiological model of temperament and character. Archives of General Psychiatry, 50, 975-990.

Deary, I. J., Battersby, S., Whiteman, M. C., Connor, J. M., Fowkes, F. G., \& HARMAR, A. (1999). Neuroticism and polymorphisms in the serotonin transporter gene. Psychological Medicine, 29, 735-739.

Du, L., BAKISH, D., \& Hrdina, P. D. (2000). Gender differences in as- sociation between serotonin transporter gene polymorphism and personality traits. Psychiatric Genetics, 10, 159-164.

Egan, M. F., Goldberg, T. E., Kolachana, B. S., Callicott, J. H., Mazzanti, C. M., Straub, R. E., et al. (2001). Effect of COMT Val108/158 Met genotype on frontal lobe function and risk for schizophrenia. Proceedings of the National Academy of Sciences, 98, 6917 6922.

Eggers, B., Hermann, W., Barthel, H., Sabri, O., Wagner, A., \& Hesse, S. (2003). The degree of depression in Hamilton rating scale is correlated with the density of presynaptic serotonin transporters in 23 patients with Wilson's disease. Journal of Neurology, 250, 576-580.

Eley, T. C., Sugden, K., Corsico, A., Gregory, A. M., Sham, P., McGuFFIN, P., ET AL. (2004). Gene-environment interaction analysis of serotonin system markers with adolescent depression. Molecular Psychiatry, 9, 908-915.

Fan, J., Fossella, J., Sommer, T., Wu, Y., \& Posner, M. I. (2003). Mapping the genetic variation of executive attention onto brain activity. Proceedings of the National Academy of Sciences, 100, 7406-7411.

Flory, J. D., Manuck, S. B., Ferrell, R. E., Dent, K. M., Peters, D. G., \& Muldoon, M. F. (1999). Neuroticism is not associated with the serotonin transporter (5-HTTLPR) polymorphism. Molecular Psychiatry, 4, 93-96.

Furmark, T., Tillforo, M., Garpenstrand, H., Marteinsdottir, I. Langstrom, B., Oreland, L., \& Fredrikson, M. (2004). Serotonin transporter polymorphism related to amygdala excitability and symptom severity in patients with social phobia. Neuroscience Letters, 362, 189-192.

Garpenstrand, H., Annas, P., Ekblom, J., Oreland, L., \& Fredrikson, M. (2001). Human fear conditioning is related to dopaminergic and serotonergic biological markers. Behavioral Neuroscience, $\mathbf{1 1 5}$ 358-364.

Gaspar, P. (2004). Des modèles génétiques pour comprendre le rôle de la sérotonine au cours du développement [Genetic models to understand how serotonin acts during development]. Journal de la Société de Biologie, 198, 18-21.

Gelernter, J., Kranzler, H., \& Cubells, J. F. (1997). Serotonin transporter protein (SLC6A4) allele and haplotype frequencies and linkage disequilibria in African- and European-American and Japanese populations and in alcohol-dependent subjects. Human Genetics, $101,243-246$

Gillespie, N. A., Whitfield, J. B., Williams, B., Heath, A. C., \& Martin, N. G. (2005). The relationship between stressful life events, the serotonin transporter (5-HTTLPR) genotype and major depression. Psychological Medicine, 35, 101-111.

Glatt, C. E., \& Freimer, N. B. (2002). Association analysis of candidate genes for neuropsychiatric disease: The perpetual campaign. Trends in Genetics, 18, 307-312.

Gu, Q. (2002). Neuromodulatory transmitter systems in the cortex and their role in cortical plasticity. Neuroscience, 111, 815-835.

Hariri, A. R., Bookheimer, S. Y., \& Mazziotta, J. C. (2000). Modulating emotional responses: Effects of a neocortical network on the limbic system. NeuroReport, 11, 43-48.

Hariri, A. R., Drabant, E. M., Munoz, K. E., Kolachana, B. S., Mattay, V. S., Egan, M. F., \& Weinberger, D. R. (2005). A susceptibility gene for affective disorders and the response of the human amygdala. Archives of General Psychiatry, 62, 146-152.

Hariri, A. R., Goldberg, T. E., Mattay, V. S., Kolachana, B. S., Callicott, J. H., Egan, M. F., \& Weinberger, D. R. (2003). Brainderived neurotrophic factor VAL66MET polymorphism affects human memory-related hippocampal activity and predicts memory performance. Journal of Neuroscience, 23, 6690-6694.

Hariri, A. R., Mattay, V. S., Tessitore, A., Fera, F., Smith, W. G., \& Weinberger, D. R. (2002). Dextroamphetamine modulates the response of the human amygdala. Neuropsychopharmacology, 27, 1036-1040.

Hariri, A. R., Mattay, V. S., Tessitore, A., Kolachana, B., Fera, F. Goldman, D., ET AL. (2002). Serotonin transporter genetic variation and the response of the human amygdala. Science, 297, 400-403.

Hariri, A. R., Tessitore, A., Mattay, V. S., Fera, F., \& Weinberger, D. R. (2002). The amygdala response to emotional stimuli: A comparison of faces and scenes. NeuroImage, 17, 317-323. 
Hariri, A. R., \& Weingerger, D. R. (2003). Imaging genomics. British Medical Bulletin, 65, 259-270.

Heils, A., Teufel, A., Petri, S., Stober, G., Riederer, P., Bengel, D., \& LeSCH, K. P. (1996). Allelic variation of human serotonin transporter gene expression. Journal of Neurochemistry, 66, 2621-2624.

Heinz, A., Braus, D. F., Smolka, M. N., Wrase, J., Puls, I., HerMANN, D., ET AL. (2005). Amygdala-prefrontal coupling depends on a genetic variation of the serotonin transporter. Nature Neuroscience, 8, 20-21.

Heinz, A., Jones, D. W., Bissette, G., Hommer, D., Ragan, P., Knable, M., ET AL. (2002). Relationship between cortisol and serotonin metabolites and transporters in alcoholism [correction of alcoholism]. Pharmacopsychiatry, 35, 127-134.

Heinz, A., Jones, D. W., Mazzanti, C., Goldman, D., Ragan, P., Hommer, D., ET AL. (2000). A relationship between serotonin transporter genotype and in vivo protein expression and alcohol neurotoxicity. Biological Psychiatry, 47, 643-649.

Holmes, A., Li, Q., Murphy, D. L., Gold, E., \& Crawley, J. N. (2003). Abnormal anxiety-related behavior in serotonin transporter null mutant mice: The influence of genetic background. Genes, Brain \& Behavior, 2, 365-380.

Hranilovic, D., StefulJ, J., Schwab, S., Borrmann-Hassenbach, M., Albus, M., JerneJ, B., \& Wildenauer, D. (2004). Serotonin transporter promoter and intron 2 polymorphisms: Relationship between allelic variants and gene expression. Biological Psychiatry, 55, 10901094.

Hu, X., Oroszi, G., Chun, J., Smith, T. L., Goldman, D., \& Schuckit, M. A. (2005). An expanded evaluation of the relationship of four alleles to the level of response to alcohol and the alcoholism risk. Alcoholism, Clinical \& Experimental Research, 29, 8-16.

Katsuragi, S., Kunugi, H., Sano, A., Tsutsumi, T., Isogawa, K., Nanko, S., \& AKIYoshi, J. (1999). Association between serotonin transporter gene polymorphism and anxiety-related traits. Biological Psychiatry, 45, 368-370.

Kaufman, J., Yang, B. Z., Douglas-Palumberi, H., Houshyar, S., LipschitZ, D., Krystal, J. H., \& Gelernter, J. (2004). Social supports and serotonin transporter gene moderate depression in maltreated children. Proceedings of the National Academy of Sciences, 101, 17316-17321.

Kendler, K. S., Kuhn, J. W., Vittum, J., Prescott, C. A., \& Riley, B. (2005). The interaction of stressful life events and a serotonin transporter polymorphism in the prediction of episodes of major depression: A replication. Archives of General Psychiatry, 62, 529-535.

KRUBitZer, L., \& KAHN, D. M. (2003). Nature versus nurture revisited: An old idea with a new twist. Progress in Neurobiology, 70, 33-52.

LeDoux, J. E. (2000). Emotion circuits in the brain. Annual Review of Neuroscience, 23, 155-184.

LESCH, K. P. (2001). Variation of serotonergic gene expression: Neurodevelopment and the complexity of response to psychopharmacologic drugs. European Neuropsychopharmacology, 11, 457-474.

Lesch, K. P., Bengel, D., Heils, A., Sabol, S. Z., Greenberg, B. D., PETRI, S., ET AL. (1996). Association of anxiety-related traits with a polymorphism in the serotonin transporter gene regulatory region. Science, 274, 1527-1531.

LESCH, K. P., \& Mössner, R. (1998). Genetically driven variation in serotonin uptake: Is there a link to affective spectrum, neurodevelopmental, and neurodegenerative disorders? Biological Psychiatry, 44, 179-192.

Little, K. Y., Mclaughlin, D. P., Zhang, L., Livermore, C. S., Dalack, G. W., McFinton, P. R., ET AL. (1998). Cocaine, ethanol, and genotype effects on human midbrain serotonin transporter binding sites and mRNA levels. American Journal of Psychiatry, 155, 207-213.

LUCKI, I. (1998). The spectrum of behaviors influenced by serotonin. Biological Psychiatry, 44, 151-162.

Malison, R. T., Price, L. H., Berman, R., van Dyck, C. H., Pelton, G. H., Carpenter, L., ET AL. (1998). Reduced brain serotonin transporter availability in major depression as measured by [123I]-2 betacarbomethoxy-3 beta-(4-iodophenyl)tropane and single photon emission computed tomography. Biological Psychiatry, 44, 1090-1098.

Manuck, S. B., Bleil, M. E., Petersen, K. L., Flory, J. D., Mann,
J. J., Ferrell, R. E., \& Muldoon, M. F. (2005). The socio-economic status of communities predicts variation in brain serotonergic responsivity. Psychological Medicine, 35, 519-528.

Manuck, S. B., Flory, J. D., Ferrell, R. E., Dent, K. M., Mann, J. J., \& Muldoon, M. F. (1999). Aggression and anger-related traits associated with a polymorphism of the tryptophan hydroxylase gene. Biological Psychiatry, 45, 603-614.

Manuck, S. B., Flory, J. D., Ferrell, R. E., Mann, J. J., \& MulDOON, M. F. (2000). A regulatory polymorphism of the monoamine oxidase: A gene may be associated with variability in aggression, impulsivity, and central nervous system serotonergic responsivity. Psychiatry Research, 95, 9-23.

Manuck, S. B., Flory, J. D., Ferrell, R. E., \& Muldoon, M. F. (2004). Socio-economic status covaries with central nervous system serotonergic responsivity as a function of allelic variation in the serotonin transporter gene-linked polymorphic region. Psychoneuroendocrinology, 29, 651-668.

Mathews, T. A., Fedele, D. E., Coppelli, F. M., Avila, A. M., MurPHY, D. L., \& ANDrews, A. M. (2004). Gene dose-dependent alterations in extraneuronal serotonin but not dopamine in mice with reduced serotonin transporter expression. Journal of Neuroscience Methods, 140, 169-181.

MAYBeRG, H. S. (2003a). Modulating dysfunctional limbic-cortical circuits in depression: Towards development of brain-based algorithms for diagnosis and optimised treatment. British Medical Bulletin, $\mathbf{6 5}$, 193-207.

Mayberg, H. S. (2003b). Positron emission tomography imaging in depression: A neural systems perspective. Neuroimaging Clinics of North America, 13, 805-815.

Mazzanti, C. M., Lappalainen, J., Long, J. C., Bengel, D., NaukKARINEN, H., EgGERT, M., ET AL. (1998). Role of the serotonin transporter promoter polymorphism in anxiety-related traits. Archives of General Psychiatry, 55, 936-940.

Melke, J., Landen, M., Baghei, F., Rosmond, R., Holm, G., BJornTORP, P., ET AL. (2001). Serotonin transporter gene polymorphisms are associated with anxiety-related personality traits in women. American Journal of Medical Genetics, 105, 458-463.

Moffitt, T. E., CASPI, A., \& RutTer, M. (2005). Strategy for investigating interactions between measured genes and measured environments. Archives of General Psychiatry, 62, 473-481.

Moreno, F. A., Rowe, D. C., Kaiser, B., Chase, D., Michaels, T., GeLernter, J., \& Delgado, P. L. (2002). Association between a serotonin transporter promoter region polymorphism and mood response during tryptophan depletion. Molecular Psychiatry, 7, 213-216.

Munafo, M. R., Clark, T., \& Flint, J. (2005). Does measurement instrument moderate the association between the serotonin transporter gene and anxiety-related personality traits? A meta-analysis. Molecular Psychiatry, 10, 415-419.

Murphy, D. L., Andrews, A. M., Wichems, C. H., Li, Q., Tohda, M., \& GREENBERG, B. (1998). Brain serotonin neurotransmission: An overview and update with an emphasis on serotonin subsystem heterogeneity, multiple receptors, interactions with other neurotransmitter systems, and consequent implications for understanding the actions of serotonergic drugs. Journal of Clinical Psychiatry, 59(Suppl. 15), 4-12.

Neumeister, A., Konstantinidis, A., Stastny, J., Schwarz, M. J. Vitouch, O., Willeit, M., et AL. (2002). Association between serotonin transporter gene promoter polymorphism (5HTTLPR) and behavioral responses to tryptophan depletion in healthy women with and without family history of depression. Archives of General Psychiatry, 59, 613-620.

New, A. S., Gelernter, J., Yovell, Y., Trestman, R. L., Nielsen, D. A., Silverman, J., ET AL. (1998). Tryptophan hydroxylase genotype is associated with impulsive-aggression measures: A preliminary study. American Journal of Medical Genetics, 81, 13-17.

Nielsen, D. A., Goldman, D., Virkkunen, M., Tokola, R., RawlINGS, R., \& LinNoILA, M. (1994). Suicidality and 5-hydroxyindoleacetic acid concentration associated with a tryptophan hydroxylase polymorphism. Archives of General Psychiatry, 51, 34-38.

Nielsen, D. A., Jenkins, G. L., Stefanisko, K. M., Jefferson, K. K., \& Goldman, D. (1997). Sequence, splice site and population fre- 
quency distribution analyses of the polymorphic human tryptophan hydroxylase intron 7. Molecular Brain Research, 45, 145-148.

Nielsen, D. A., Virkkunen, M., Lappalainen, J., Eggert, M., Brown, G. L., LoNG, J. C., ET AL. (1998). A tryptophan hydroxylase gene marker for suicidality and alcoholism. Archives of General Psychiatry, 55, 593-602.

Nolan, K. A., Volavka, J., Lachman, H. M., \& Saito, T. (2000). An association between a polymorphism of the tryptophan hydroxylase gene and aggression in schizophrenia and schizoaffective disorder. Psychiatric Genetics, 10, 109-115.

Pezawas, L., Meyer-Lindenberg, A., Drabant, E. M., Verchinski, B. A., Munoz, K. E., Kolachana, B. S., ET AL. (2005). 5-HTTLPR polymorphism impacts human cingulate-amygdala interactions: A genetic susceptibility mechanism for depression. Nature Neuroscience, 8, 828-834.

Phillips, M. L., Drevets, W. C., Rauch, S. L., \& Lane, R. (2003a) Neurobiology of emotion perception I: The neural basis of normal emotion perception. Biological Psychiatry, 54, 504-514.

Phillips, M. L., Drevets, W. C., Rauch, S. L., \& Lane, R. (2003b). Neurobiology of emotion perception II: Implications for major psychiatric disorders. Biological Psychiatry, 54, 515-528.

ReIf, A., \& Lesch, K. P. (2003). Toward a molecular architecture of personality. Behavioural Brain Research, 139, 1-20.

SAdiKot, A. F., \& PARENT, A. (1990). The monoaminergic innervation of the amygdala in the squirrel monkey: An immunohistochemical study. Neuroscience, 36, 431-447.

Schinka, J. A., Busch, R. M., \& Robichaux-Keene, N. (2004). A meta-analysis of the association between the serotonin transporter gene polymorphism (5-HTTLPR) and trait anxiety. Molecular Psychiatry, 9, 197-202.

Sen, S., Burmeister, M., \& Ghosh, D. (2004). Meta-analysis of the association between a serotonin transporter promoter polymorphism (5-HTTLPR) and anxiety-related personality traits. American Journal of Medical Genetics, 127B, 85-89.
Shen, H. W., Hagino, Y., Kobayashi, H., Shinohara-TanaKa, K., IKEDA, K., Yамамото, H., ET AL. (2004). Regional differences in extracellular dopamine and serotonin assessed by in vivo microdialysis in mice lacking dopamine and/or serotonin transporters. Neuropsychopharmacology, 29, 1790-1799.

Smith, H. R., Daunais, J. B., Nader, M. A., \& Porrino, L. J. (1999). Distribution of $[3 \mathrm{H}]$ citalopram binding sites in the nonhuman primate brain. Annals of the New York Academy of Sciences, 877, 700-702.

Tessitore, A., Hariri, A. R., Fera, F., Smith, W. G., Chase, T. N., HydE, T. M., ET AL. (2002). Dopamine modulates the response of the human amygdala: A study in Parkinson's disease. Journal of Neuroscience, 22, 9099-9103.

Walther, D. J., \& BAder, M. (2003). A unique central tryptophan hydroxylase isoform. Biochemical Pharmacology, 66, 1673-1680.

Walther, D. J., Peter, J. U., Bashammakh, S., Hortnagl, H., Voits, M., Fink, H., \& Bader, M. (2003). Synthesis of serotonin by a second tryptophan hydroxylase isoform. Science, 299, 76.

Whale, R., Clifford, E. M., \& Cowen, P. J. (2000). Does mirtazapine enhance serotonergic neurotransmission in depressed patients? Psychopharmacology, 148, 325-326.

Willeit, M., Praschak-Rieder, N., Neumeister, A., Pirker, W. Asenbaum, S., Vitouch, O., et AL. (2000). [123I]-beta-CIT SPECT imaging shows reduced brain serotonin transporter availability in drug-free depressed patients with seasonal affective disorder. Biological Psychiatry, 47, 482-489.

Williams, R. B., Marchuk, D. A., Gadde, K. M., Barefoot, J. C., GrichNiK, K., Helms, M. J., ET AL. (2003). Serotonin-related gene polymorphisms and central nervous system serotonin function. Neuropsychopharmacology, 28, 533-541.

Zalsman, G., Anderson, G. M., Peskin, M., Frisch, A., King, R. A. VEKSLERCHIK, M., ET AL. (2005). Relationships between serotonin transporter promoter polymorphism, platelet serotonin transporter binding and clinical phenotype in suicidal and non-suicidal adolescent inpatients. Journal of Neural Transmission, 112, 309-315. 